Article

\title{
Fungal Tolerance: An Alternative for the Selection of Fungi with Potential for the Biological Recovery of Precious Metals
}

\author{
Rosalba Argumedo-Delira ${ }^{1,2, * \mathbb{C} \text {, Mario J. Gómez-Martínez }}{ }^{3(\mathbb{D})}$ and Ramiro Uribe-Kaffure ${ }^{4}(\mathbb{D})$ \\ 1 Unidad de Servicios de Apoyo en Resolución Analítica (SARA), Universidad Veracruzana, \\ Luis Castelazo Ayala s/n, Col. Industrial Animas, Xalapa, Veracruz 91190, Mexico \\ 2 Posgrado en Ciencias Agropecuarias, Facultad de Ciencias Agrícolas, Universidad Veracruzana, \\ Circuito Gonzalo Aguirre Beltrán s/n, Xalapa, Veracruz 91000, Mexico \\ 3 Departamento de Producción y Sanidad Vegetal, Facultad de Ingeniería Agronómica, \\ Universidad del Tolima, Barrio Santa Helena, Ibagué, Tolima 730006299, Colombia; mjgomez@ut.edu.co \\ 4 Departamento de Física, Facultad de Ciencias, Universidad del Tolima, Barrio Santa Helena, Ibagué, \\ Tolima 730006299, Colombia; rauribe@ut.edu.co \\ * Correspondence: rargumedo@uv.mx; Tel.: +52-011-5222-8842-1700 (ext. 13917)
}

Received: 1 October 2020; Accepted: 13 November 2020; Published: 15 November 2020

\begin{abstract}
The behavior of various filamentous fungi in the presence of metals such as $\mathrm{Cu}, \mathrm{Zn}, \mathrm{Ni}, \mathrm{Fe}$, $\mathrm{Mn}$, and $\mathrm{V}$ has been widely reported. However, there is little information regarding metals such as $\mathrm{Au}, \mathrm{Ag}$ and $\mathrm{Pt}$ that are not in the form of nanoparticles. The growth of eight filamentous fungi was evaluated at increasing doses of $\mathrm{Au}, \mathrm{Ag}$ and Pt. The fungi were reactivated in Petri dishes with potato dextrose agar. Subsequently, individual mycelial disks from each strain were inoculated in PDA plates with the following doses of $\mathrm{AuCl}_{3}, \mathrm{Ag}_{2} \mathrm{SO}_{4}$ and $\mathrm{PtCl}_{4}: 0,50,150$ and $300 \mathrm{mg} \mathrm{L}^{-1}$, respectively. The plates were then incubated for 20 days-a period in which the diameter of the colony was measured every $24 \mathrm{~h}$. Au showed the highest toxicity for the tested fungi. All silver doses decreased the growth of most of the fungi, while platinum did not cause any inhibitory effect on the growth of the eight tested fungi. With a simple test, it was possible to observe the effect of precious metals (PMs) on the growth of filamentous fungi and consider their possible biotechnological applications in the recovery of PMs from primary or secondary sources.
\end{abstract}

Keywords: filamentous fungi; metals; secondary sources; primary sources

\section{Introduction}

Precious metals (PMs) are a group of elements ( $\mathrm{Au}, \mathrm{Ag}, \mathrm{Pt}, \mathrm{Pd}, \mathrm{Ir}, \mathrm{Rh}, \mathrm{Os}$ and $\mathrm{Ru}$ ) that have taken on great importance in recent years due to their diverse applications in the medical and high-technology industries; thus, their demand and price have increased [1-4]. The problem that surrounds the PMs is that they are quite diluted in the Earth's crust, and current extraction-refining methods are challenging, expensive and not environmentally friendly [3-6]. Considering the above-mentioned factors, it is necessary to develop new biotechnologies for the extraction/recovery of PMs from diverse materials. In the literature, there are a large number of reports on the interaction presented by metals such as $\mathrm{K}, \mathrm{Na}, \mathrm{Mg}, \mathrm{Ca}, \mathrm{Mn}, \mathrm{Fe}, \mathrm{Cu}, \mathrm{Zn}, \mathrm{Co}, \mathrm{Ni}, \mathrm{Al}, \mathrm{Cd}, \mathrm{Hg}$ and $\mathrm{Pb}$ with bacteria, fungi and algae primarily [7-15], but the studies are limited to a great extent to the interaction with PMs that are in the form of nanoparticles. For instance, it was found that some bacteria play an important role in the biogeochemical cycle of $\mathrm{Au}$, since microbes have been mobilizing $\mathrm{Au}$ for more than hundreds of years [16-20]. This ability has been used to generate biotechnological leaching techniques that allow $\mathrm{Au}$ to be recovered from refractory minerals [21-28]. Furthermore, research on the recovery of Au from 
secondary sources (electronic waste and jewelry waste) using microorganisms has gained importance in recent years. Studies have reported Au solubilization (20-90\%) from printed circuit boards (PCBs) from cell phones and computers by cyanogenic bacteria (Chromobacterium violaceum, Bacillus megaterium and Pseudomonas balearica) under different culture conditions [29-35]. In the case of filamentous fungi, there is less information; however, for instance, it has been mentioned that Aspergillus niger is capable of recovering Au from secondary sources such as PCBs from cell phones and computers [36-38].

On the other hand, even though Ag has been reported as a highly toxic metal for most microorganisms, some bacteria are able to accumulate and reduce it [39-42]. Among these bacteria is the mixture of Acidithiobacillus ferroxidans and Acidithiobacillus thiooxidans, which is capable of leaching Ag from sulfurous minerals [43]. Research was also carried out to create biotechnological techniques with which $\mathrm{Ag}$ can be recovered from refractory minerals, but to a lesser extent than for Au [44-46]. Under other conditions, it had been shown that the recovery of Ag by microorganisms from secondary sources is poor. Brandl et al. [31] report that Pseudomonas plecoglossicida can mobilize around 5\% of Ag found in jewelry waste dust in one-day incubation. Similarly, Kumar et al. [33] report that Pseudomonas balearica managed to recover $33.8 \%$ of $\mathrm{Ag}$ from a PCB pulp, with a density of $10 \mathrm{~g} \mathrm{~L}^{-1}$ and at $\mathrm{pH} 9.0$.

Regarding the information about the interaction of $\mathrm{Pt}$ with microorganisms, it has been reported that cultures of the halophilic bacteria of the families Halomonasae, Bacillaceae and Idiomarinaceae have recovered $98 \%$ of $\mathrm{Pt}$ (II) and $97 \%$ of $\mathrm{Pt}$ (IV) at $\mathrm{pH} 2$, in a time of 3 to $21 \mathrm{~h}$, from solutions of $\mathrm{K}_{2} \mathrm{Pt}(\mathrm{II}) \mathrm{Cl}_{4}$ and $\mathrm{K}_{2} \mathrm{Pt}(\mathrm{IV}) \mathrm{Cl}_{6}$ at $100 \mathrm{mg} \mathrm{L}^{-1}$ [47]. In addition, for secondary sources of Pt, Brandl et al. have reported the recovery of $\mathrm{Pt}(0.2 \%)$ from waste from automobile catalytic converters using cyanogenic bacteria [31].

As can be seen, most of the mentioned studies are oriented towards bacteria and, in a lesser extent, towards filamentous fungi. Thus, gathering additional information about the interaction of filamentous fungi with $\mathrm{Ag}$ and $\mathrm{Pt}$ is relevant to find new biotechnological applications.

The present investigation focused on evaluating the effect of increasing doses of $\mathrm{Au}, \mathrm{Ag}$ and Pt on the growth of A. niger, Trichoderma harzianum, Trichoderma koningiopsis, Trichoderma viridescens, Trichoderma sp., Hypocrea lixii, Fusarium oxysporum and Fusarium solani in order to use fungal tolerance as a simple tool for the selection of the fungi with the potential to be used in the recovery of $\mathrm{Au}, \mathrm{Ag}$ and Pt from primary or secondary sources.

\section{Materials and Methods}

\subsection{Fungal Strains}

A. niger MX5, T. harzianum MX2 and F. oxysporum MX17 were isolated from soil contaminated with metals, and H. lixii MXPE12 and F. solani MXPE15 were taken from an electronic board, with both samples coming from the surroundings of the El Tronconal sanitary landfill, Xalapa-Veracruz, Mexico. Additionally, T. koningiopsis MX11 and T. sp. MX13 were isolated from the rhizosphere of Liquidambar sp. at the Natura Park and T. viridescens MX1 was isolated from rhizospheric fern soil at the Library and Information Services Unit of the Universidad Veracruzana in Xalapa-Veracruz. The standard method for the isolation of filamentous fungi is described in greater detail in the work of Madrigal-Arias [48].

\subsection{Identification of Fungi}

DNA extraction from fungal strains was carried out using the method of Wilson et al. [49]. The PCR products were purified with the phenol-chloroform technique [50], and the purified products (40 ng) were sent for sequencing to the Microbial Genetic Resources Laboratory (CNRG-INIFAP) in Guadalajara, Mexico. The sequences were processed with different bioinformatic tools (BioEdit, ClustalX, Seaview, MEGA6) and on the BLAST platform for the allocation of identities, where the percentages for the species were considered to be greater than $97 \%$, with values of $95 \%$ to $96 \%$ for the genus. 


\subsection{Culture of Filamentous Fungi in a Solid Medium with Au, Ag and Pt}

For the activation of the growth of the eight filamentous fungi, they were cultivated in Petri dishes with potato dextrose agar (PDA Baker ${ }^{\circledR}$ ) at $28^{\circ} \mathrm{C}$ for 5 and 10 days. Afterwards, individual PDA disks (7 mm diameter) with each fungal strain were extracted and placed on new Petri dishes with PDA. Au, $\mathrm{Ag}$ and $\mathrm{Pt}$ were supplied in the culture medium by the addition of $0,50,150$ or $300 \mathrm{mg} \mathrm{L}^{-1}$ at $\mathrm{pH} 4.0$ $\left(\mathrm{AuCl}_{3}, \mathrm{Ag}_{2} \mathrm{SO}_{4}\right.$, and $\mathrm{PtCl}_{4}$, Sigma-Aldrich $\left.{ }^{\circledR}\right)$. The Petri dishes were incubated at $28^{\circ} \mathrm{C}$ for 20 days, and the fungal growth rate was assessed by measuring the diameter of each fungal colony every $24 \mathrm{~h}$. Petri dishes without $\mathrm{Au}, \mathrm{Ag}$ and $\mathrm{Pt}$ were used as controls.

\subsection{Statistic Analysis}

A completely randomized experimental design was used for the growth evaluation of the fungal strains using an $8 \times 3 \times 4$ factorial (eight fungal strains, three metals and four doses). Each treatment had three repetitions. The obtained data were analyzed using the analysis of variance and the mean comparison test (Tukey, $\alpha=0.05$ ) with the Statistical Analysis System (SAS) program [51].

\section{Results}

\subsection{Fungal Tolerance to Au}

The results show that the growth rate sof treatments with doses of 0 and $50 \mathrm{mg} \mathrm{L}^{-1}$ did not differ statistically, from the third day onwards, for the Trichoderma and Hypocrea strains (Figures 1 and 2). Besides, no growth was observed at the $150 \mathrm{mg} \mathrm{L}^{-1}$ dose for T. harzianum MX2, T. sp. MX13 and H. lixii. However, at this gold concentration $\left(150 \mathrm{mg} \mathrm{L}^{-1}\right)$, A. niger MX5 showed the highest growth, and a recovery in the growth of T. viridescens MX1, T. koningiopsis MX11, and F. oxysporum MX17 was observed during the experiment time (Figures 1 and 2). For the $300 \mathrm{mg} \mathrm{L}^{-1}$ dose, no growth was found in any of the tested fungi.

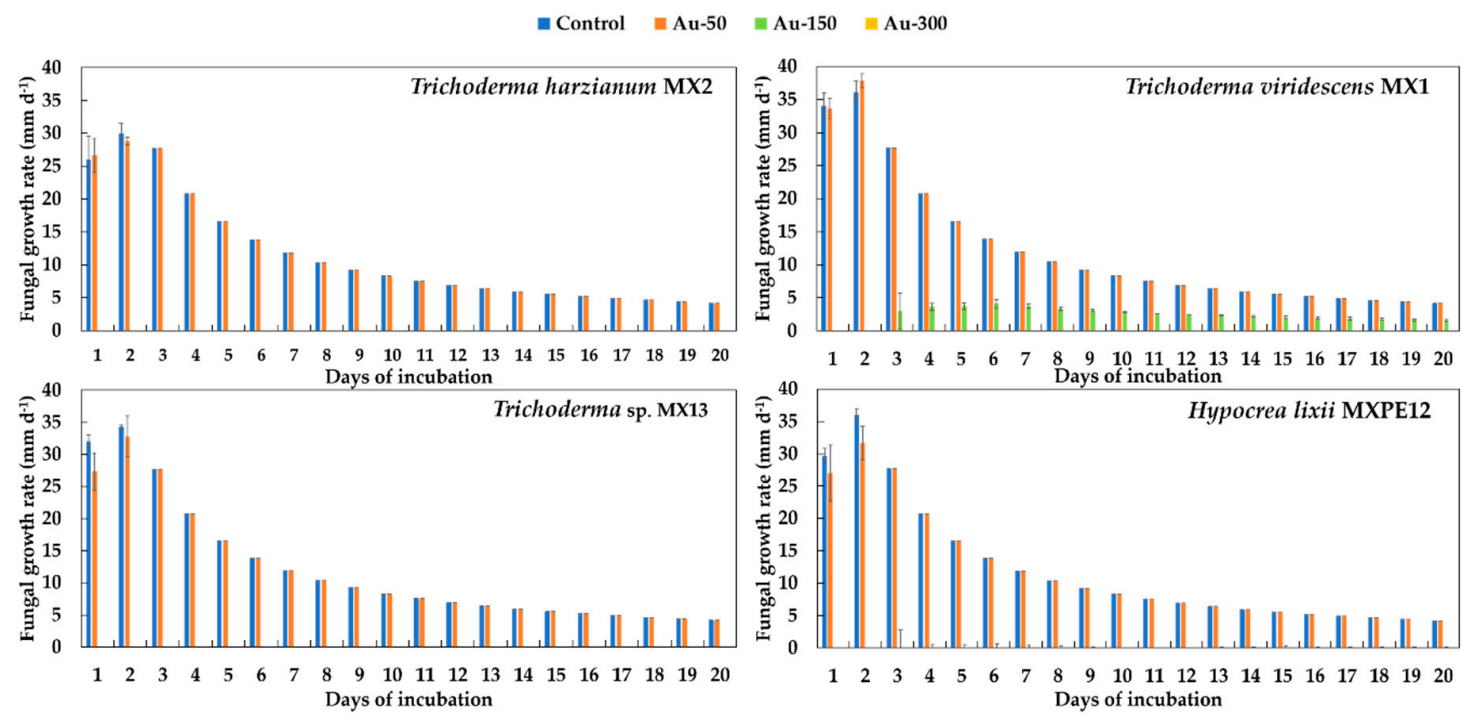

Figure 1. Fungal growth rate of filamentous fungi strains exposed to four doses of gold $\left(\mathrm{mg} \mathrm{L}^{-1}\right)(\mathrm{n}=3$, means \pm standard error).

Furthermore, the Au doses induced morphological changes in the fungi and pigmentations in the culture medium, as observed in Figure 3. For instance, in the case of the F. solani MXPE15 fungus at a dose of $50 \mathrm{mg} \mathrm{L}^{-1} \mathrm{Au}$, red pigmentation in the culture medium and purple and cottony mycelium were observed. Similarly, at the 50 and $150 \mathrm{mg} \mathrm{L}^{-1}$ doses, the mycelium of $F$. oxysporum MX17 turned purple. Additionally, A. niger MX5 showed greater sporulation as the Au dose was increased, in addition to yellow mycelium and yellow pigmentation in the culture medium at the $150 \mathrm{mg} \mathrm{L}^{-1}$ dose (Figure 3A). 


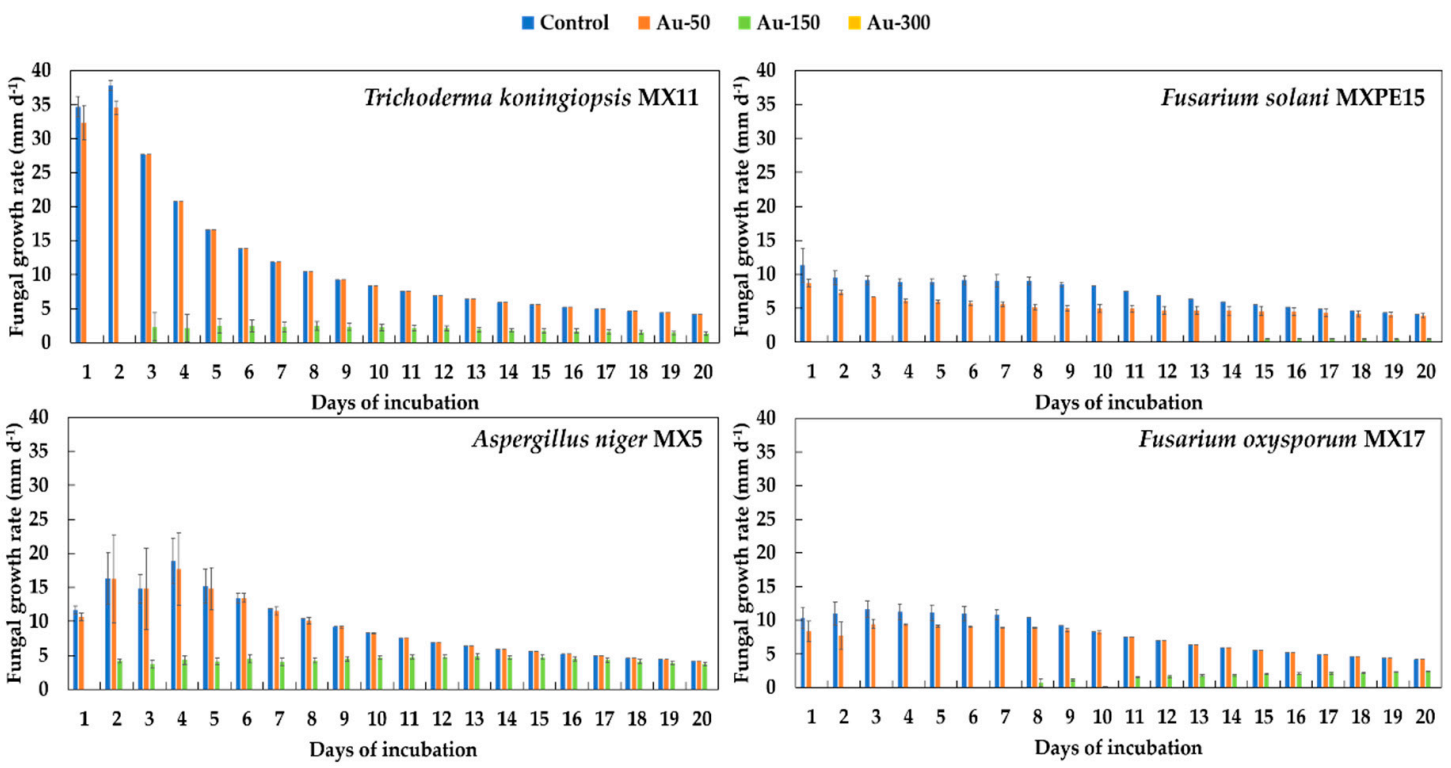

Figure 2. Fungal growth rate of four filamentous fungi strains exposed to four doses of gold (mg L $\left.{ }^{-1}\right)$.

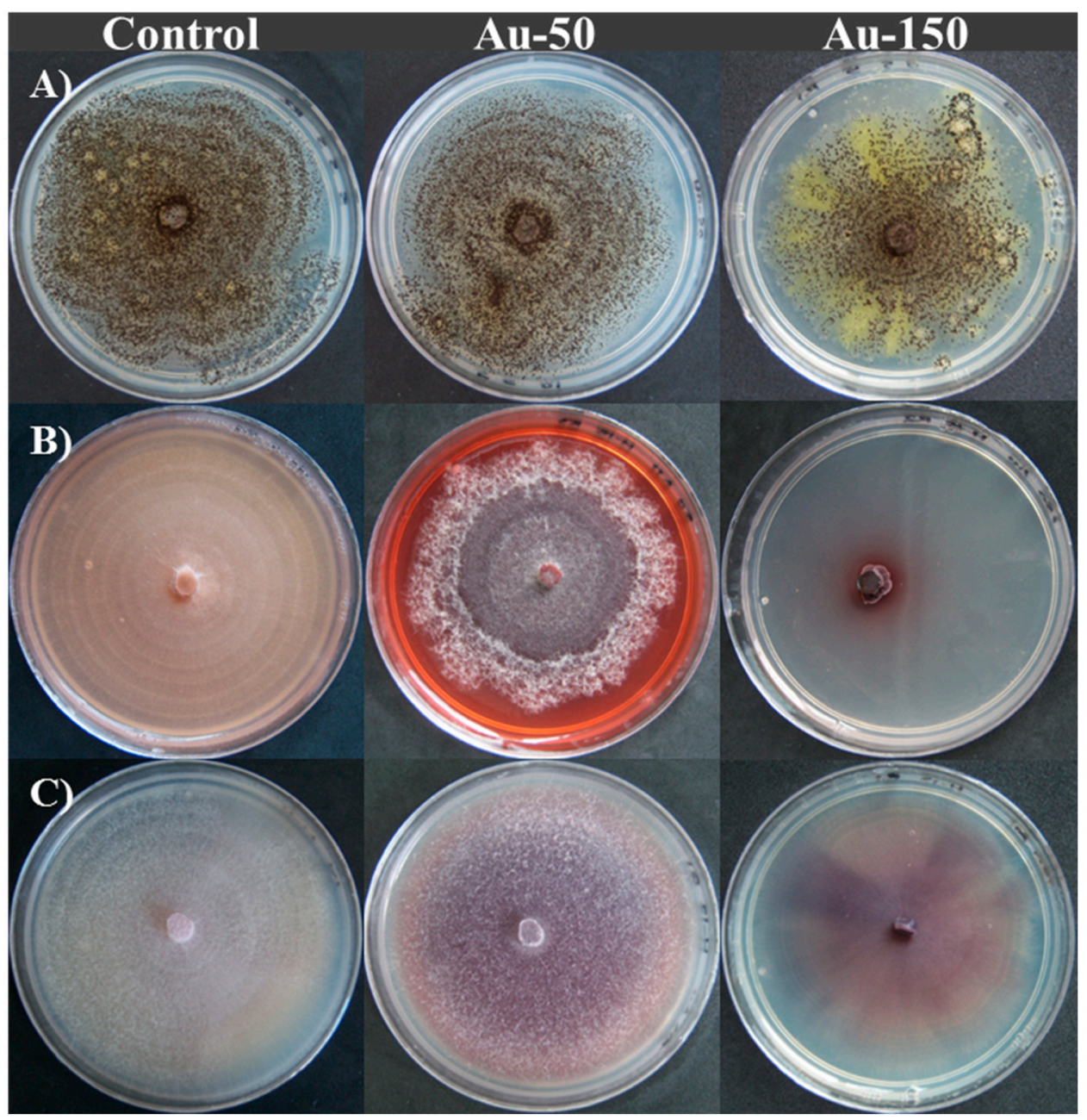

Figure 3. Morphological changes and pigment production by three strains of filamentous fungi exposed to three doses of gold for 20 days. (A) Aspergillus niger MX5, (B) Fusarium solani MXPE15 and (C) Fusarium oxysporum MX17. 


\subsection{Ag Fungal Tolerance}

In the case of $\mathrm{Ag}$, statistical differences in fungal growth rates were found on the eight tested fungi. The fungi with the highest tolerance to Ag were T. koningiopsis MX11, T. sp. MX13, and T. viridescens MX1, while F. oxysporum MX17 and F. solani MXPE15 were the least tolerant (Figures 4 and 5). The different doses played a determining role in the behavior of each fungus, since the higher the Ag dose, the lower the growth for all the treatments. Thus, for the Trichoderma species, changes in the morphology, appearance and tonality of the mycelium were observed: the yellow mycelium turned green with a powder appearance-characteristics not observed in the controls (see Figure 6A). Furthermore, the Fusarium strains showed a white mycelium when the Ag dose was increased (Figure 6C,D).

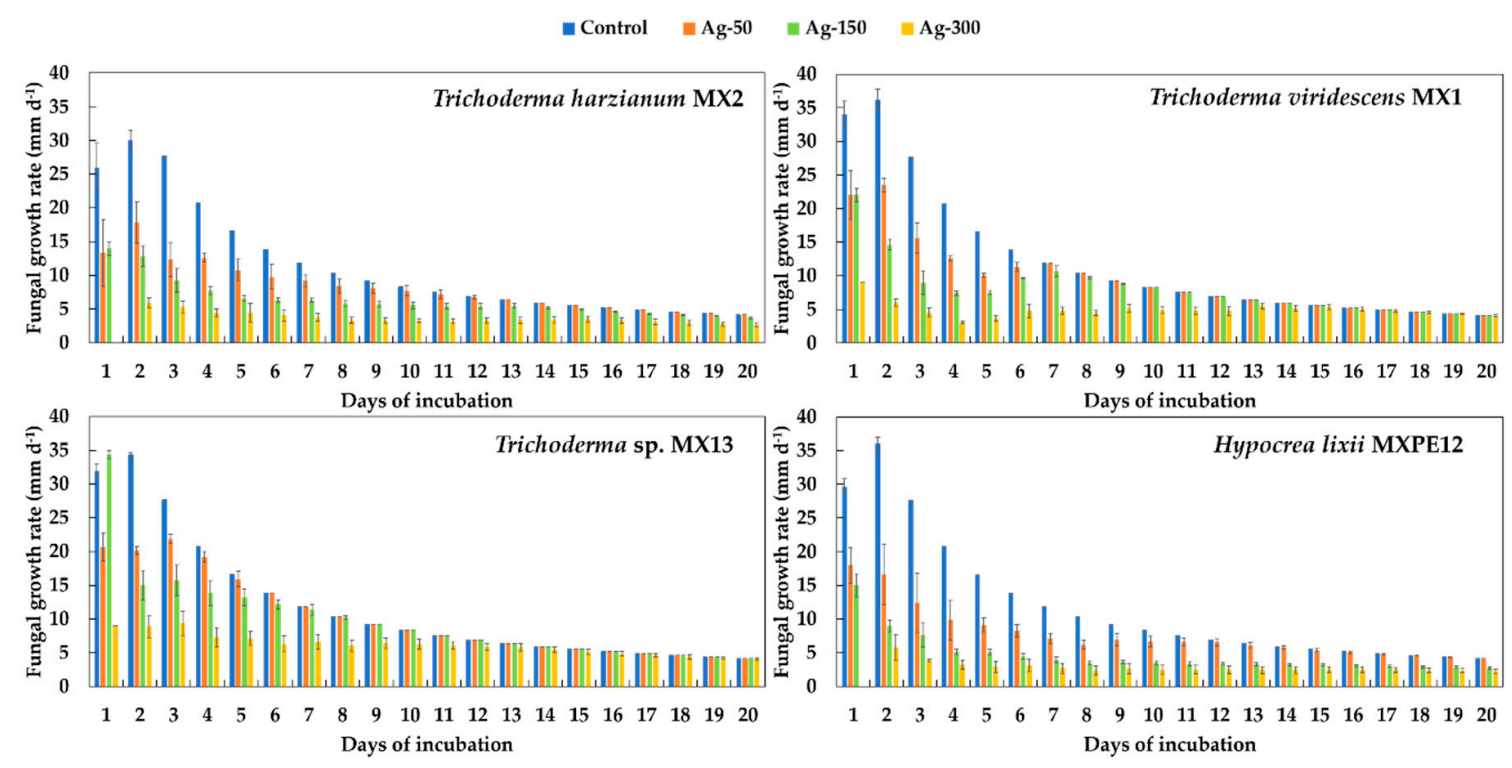

Figure 4. Fungal growth rate of four filamentous fungi strains exposed to four doses of silver $\left(\mathrm{mg} \mathrm{L}^{-1}\right)$. T. viridescens $\mathrm{MX1}$ and T. sp. MX13 were more tolerant than other strains ( $\mathrm{n}=3$, means \pm standard error).

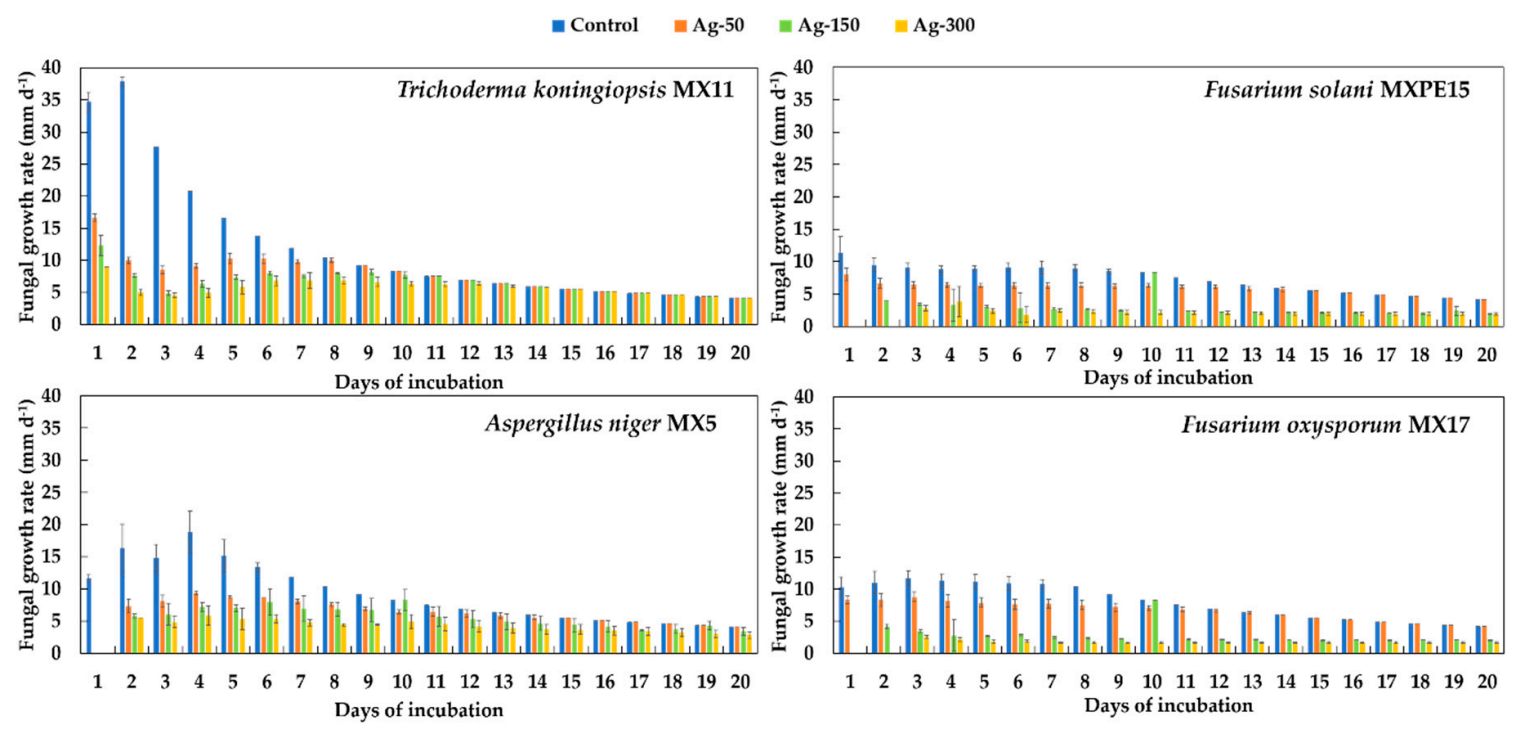

Figure 5. Fungal growth rate of four filamentous fungi strains exposed to four doses of silver $\left(\mathrm{mg} \mathrm{L}^{-1}\right)$ T. koningiopsis MX11 was more tolerant than other strains $(\mathrm{n}=3$, means \pm standard error). 


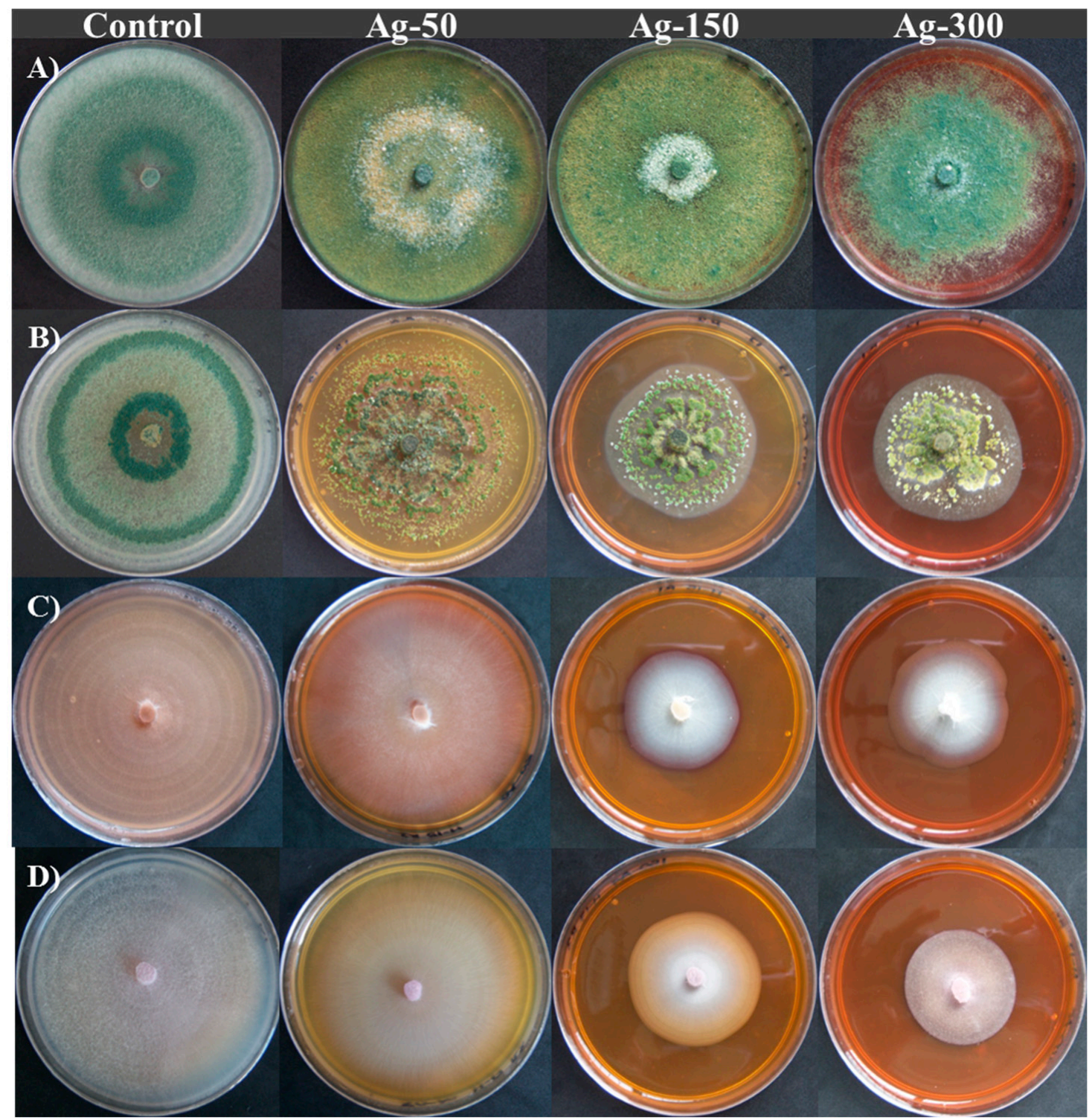

Figure 6. Morphological changes of four filamentous fungi exposed to four doses of silver for 20 days. (A) Trichoderma viridescens MX1, (B) Hypocrea lixii MXPE12, (C) Fusarium solani MXPE15 and (D) Fusarium oxysporum MX17.

\subsection{Fungal Tolerance to Pt}

Platinum did not cause an inhibition of the growth of filamentous fungi tested with the three used doses. Furthermore, no statistical differences were found in the fungal growth rates between the treatments and their respective controls from the third day of evaluation onwards for the Trichoderma and Hypocrea strains (Figure 7). However, there were statistical differences in the fungal growth rates between the controls and the treatments for the fungus F. solani MXPE15 (Figure 8). It is worth mentioning that there were no morphological changes to consider due to the presence of $\mathrm{Pt}$, as shown in Figure 9. 


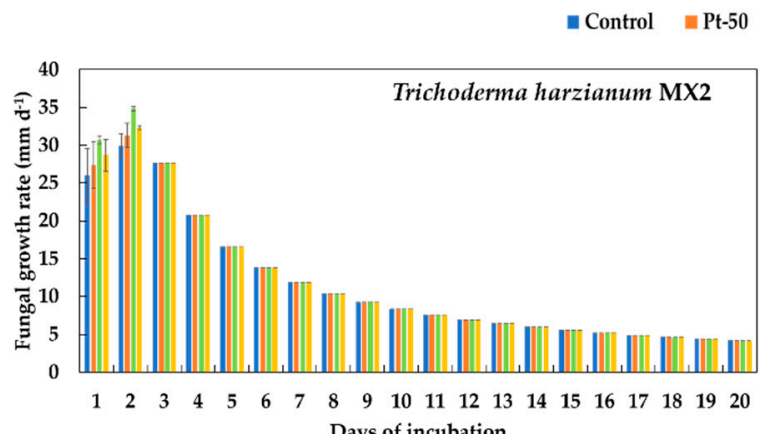

$=$ Pt-150 $=$ Pt-300
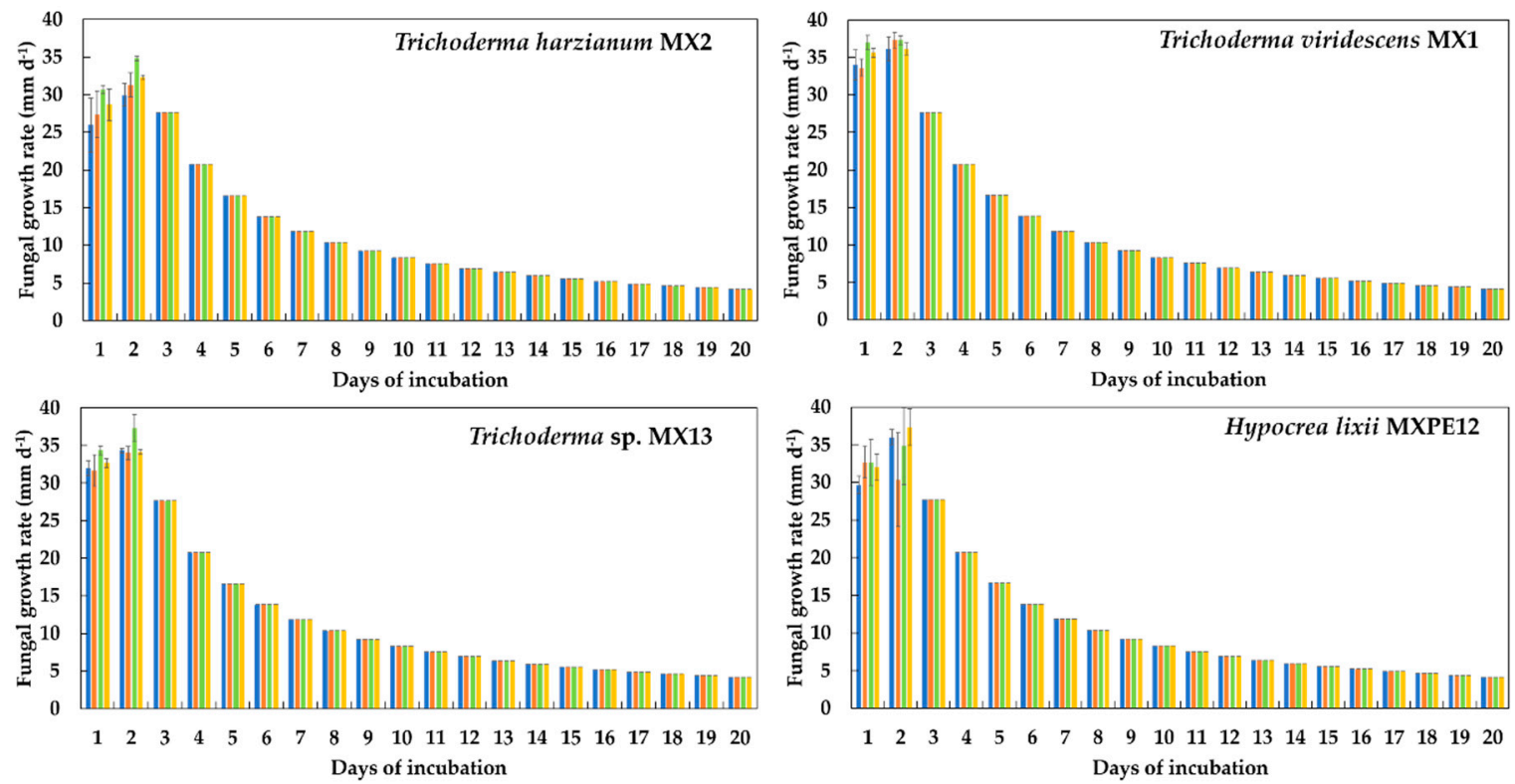

Figure 7. Fungal growth rates of four filamentous fungi strains exposed to four doses of platinum $\left(\mathrm{mg} \mathrm{L}^{-1}\right)(\mathrm{n}=3$, means \pm standard error).
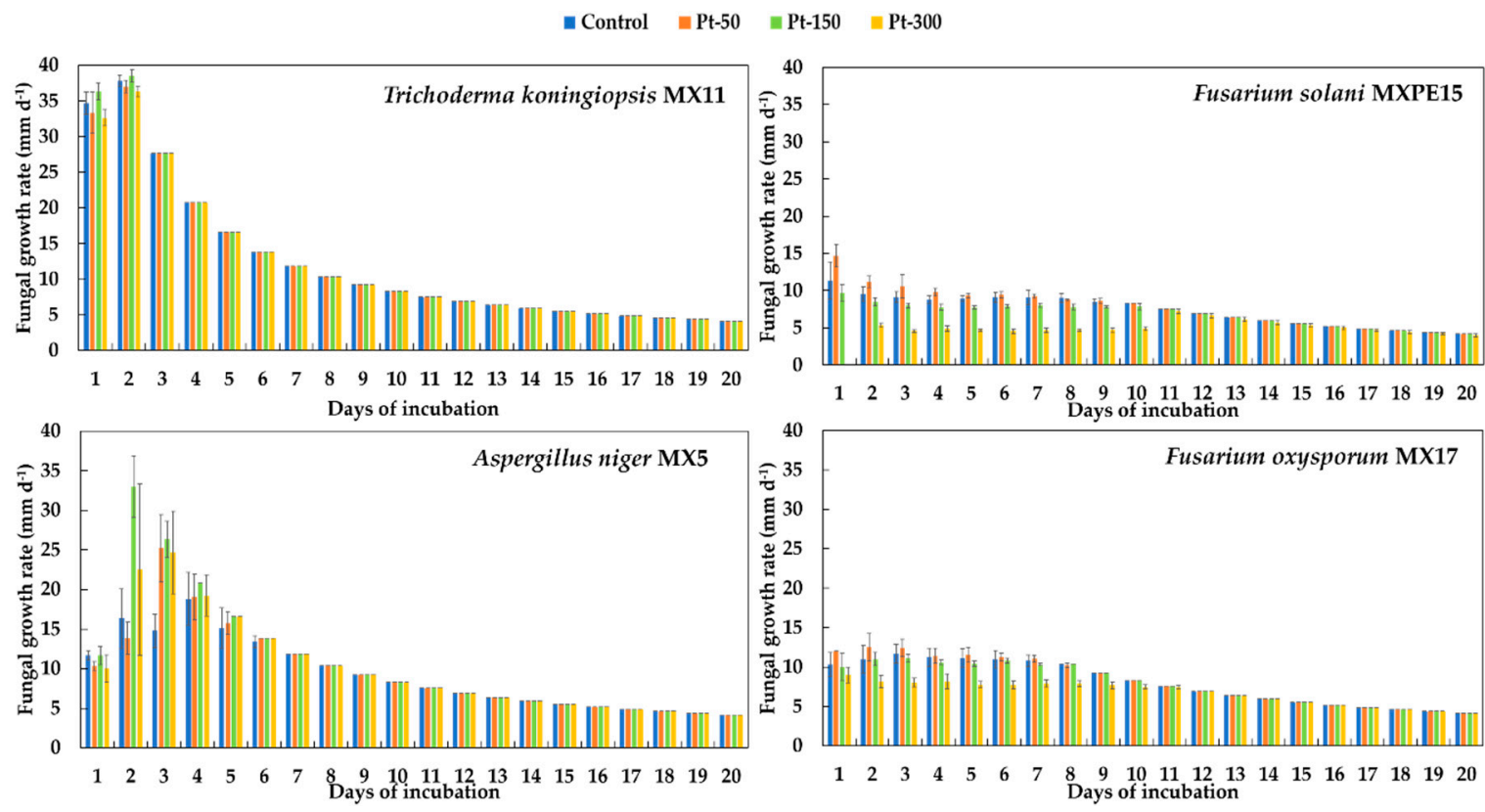

Figure 8. Fungal growth rates of four filamentous fungi strains exposed to four doses of platinum $\left(\mathrm{mg} \mathrm{L}^{-1}\right)(\mathrm{n}=3$, means \pm standard error). 


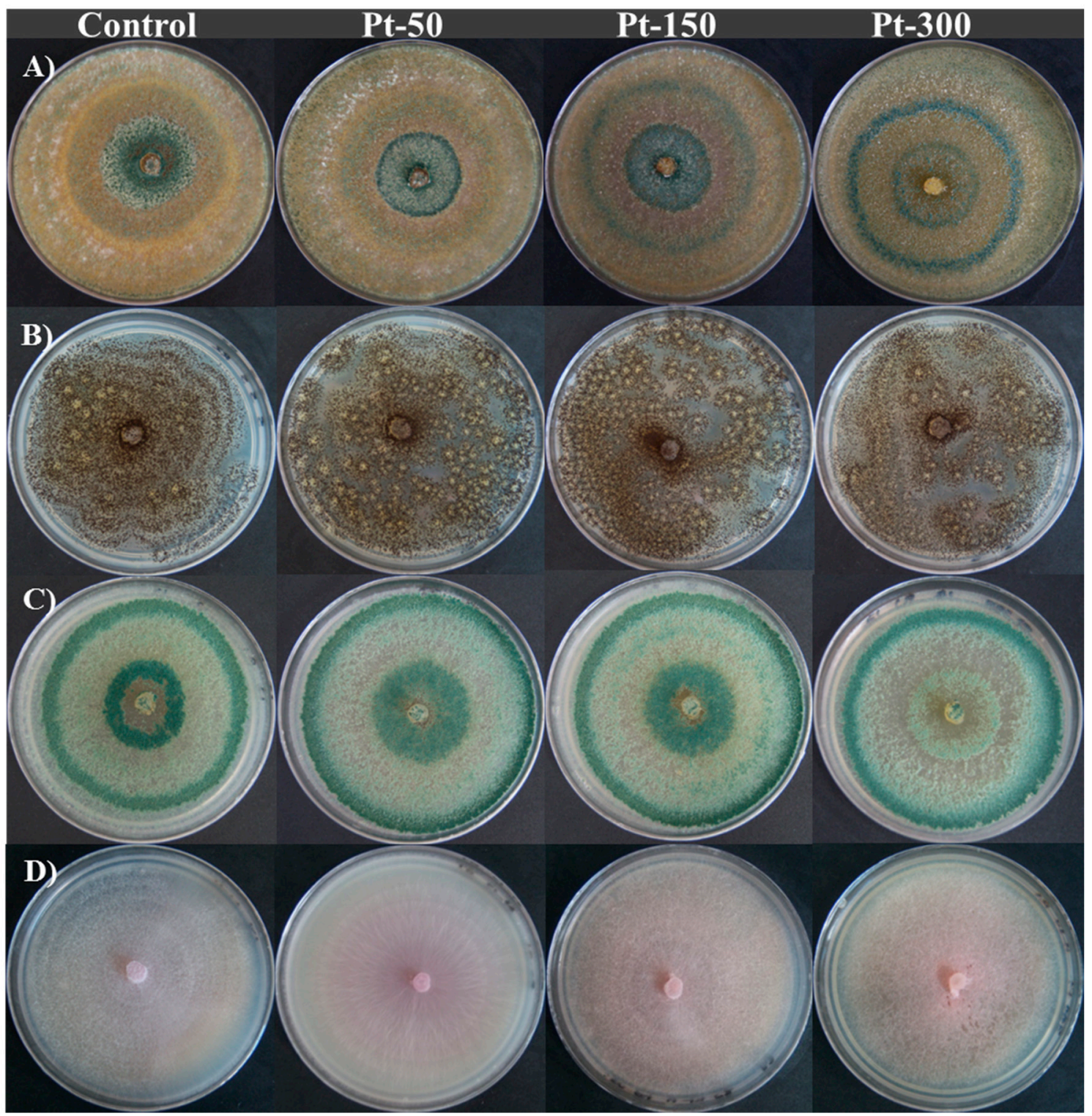

Figure 9. Morphological characteristics of four filamentous fungi exposed to four doses of platinum for 20 days. (A) Trichoderma harzianum MX2, (B) Aspergillus niger MX5, (C) Hypocrea lixii MXPE12 and (D) Fusarium oxysporum MX17.

\section{Discussion}

Morphological changes and the production of pigments in some fungi in contact with PMs, in a solid culture medium, have been reported for other metals such as $\mathrm{Cd}, \mathrm{Cu}, \mathrm{Zn}, \mathrm{Ni}$ and $\mathrm{Pb}$, showing that some fungal species reduce their growth due to metallic stress [52,53]. Such is the case of the fungi Trametes versicolor and Stereum hirsutum which, when grown in a solid medium with $\mathrm{Cd}(1 \mathrm{mM})$, showed several morphological changes in their mycelium and produced a brown pigment [52]. In the case of $\mathrm{Cu}(6$ and $10 \mathrm{mM})$, the fungi Wolfiporia cocos, Laetiporus sulfureus and T. versicolor showed significant modifications in the intensity of the color (from white to brown) and the texture (from cottony to downy) of the mycelium [54]. In this sense, pigment production has been related to the survival mechanisms used by fungi to alleviate metallic stress; it has been observed that higher concentrations of metals lead to a greater number of produced pigments [55,56].

The present investigation found that Au was more toxic to the tested filamentous fungi than $\mathrm{Ag}$ and $\mathrm{Pt}$. Some studies with other microorganisms have found that the presence of $\mathrm{Au}^{0}$ and $\mathrm{Au}^{3+}$ ions 
in trace amounts may not affect the growth of the microorganisms due to the fact that Au ions are usually deposited in the cell wall and the periplasmic membrane [57]. Therefore, this could explain why the used fungi did not show any growth inhibition for the concentration of $50 \mathrm{mg} \mathrm{L}^{-1}$. However, Karamushka and Gadd [58] indicate that the growth of Saccharomyces cerevisiae is inhibited in culture media with $\mathrm{Au}$ at doses higher than $39.4 \mathrm{mg} \mathrm{L}^{-1}$, suggesting that the used fungi are more tolerant than the mentioned yeast. As in the present study, Novelli et al. [59] found that the fungus A. niger seems to be quite tolerant to five organometallic compounds of $\mathrm{Au}$, which could indicate that, within the Aspergillus genus, the niger species are capable of tolerating a variety of Au compounds. Regarding the utility of tolerance tests for the selection of filamentous fungi in the recovery of Au from secondary or primary sources, Madrigal-Arias et al. [38] carried out previous tolerance tests for $\mathrm{Au}(0,50,100$, $300 \mathrm{mg} \mathrm{L}^{-1}$ ) from several species of the gender Aspergillus for their Au bioleaching experiments from electronic residues, finding that the consortium of the most tolerant fungi managed to leach $87 \%$ of this metal. Another example of the usefulness of these tests is the pigmentation that $F$. solani MXPE15 presented before $50 \mathrm{mg} \mathrm{L}^{-1}$ of $\mathrm{Au}$; in this situation, the fungus was tested in a liquid medium with 30 and $37 \mathrm{mg} \mathrm{L}^{-1} \mathrm{Au}$, showing that it is capable of precipitating this metal [60]. Furthermore, Díaz-Martínez et al. [61] reported that A. niger MX5 in combination with Sphingomonas sp. is capable of bioleaching approximately $1 \%$ of Au from the printed circuit boards (PCB) of cell phones.

Regarding Ag, it has been reported that fungi isolated from nearby silver mine soils can tolerate concentrations above $170 \mathrm{mg} \mathrm{L}^{-1}$ without any problem, but there has been no report on whether the fungi show morphological changes in their growth [62]. This information could only be compared with more Ag-tolerant fungi such as T. koningiopsis MX11, T. sp. MX13 and T. viridescens MX1. Concerning the usefulness of tolerance tests with silver, Díaz-Martínez [63] reported that the fungi H. lixii MXPE12 and F. oxysporum MX17 are capable of bioleaching $0.02 \%$ of $\mathrm{Ag}$ from printed circuit boards from computers. Besides, the same work showed that F. solani MXPE15 was able to leach $1 \%$ of Pd, another precious metal.

On the other hand, due to the scarce information on the effect that Pt has on filamentous fungi, it is not possible to fully compare the results obtained from the effect that this precious metal has on its growth. However, in bacteria, the presence of platinum $\left(\mathrm{Cl}_{6} \mathrm{Pt}^{2-}, 75 \mathrm{mg} \mathrm{L}^{-1}\right)$ inhibits growth in Escherichia coli B, E. coli C, E. coli K12, Aerobacter aerogenes, Alcaligenes faecalis, Proteus mirabilis, Pseudomonas aeuroginosa, Klebsiella pneumonia, Lactobacillus sp. and Serratia marcescens, which contrasts with the results that we observed in the fungal genera Trichoderma, Aspergillus, Hypocrea and Fusarium. This implies that the chemical form in which platinum is found is a factor to consider for microbial tolerance $[64,65]$. It is not ruled out that, in future research, the filamentous fungi with a higher tolerance to precious metals found in this research could be used in other studies to recover some of the precious metals contained in primary or secondary sources, reaffirming the usefulness of the fungal tolerance test as a tool for the selection of fungal strains with biotechnological potential.

Finally, it is important to mention that the costs for the implementation of this trial were not estimated. However, we assume that by using cheaper culture media (for instance, media based on agri-food residues) and perhaps recovering the precious metals from the media already used (by chemical and biological techniques), the testing costs could be considerably reduced.

\section{Conclusions}

The study shows that PM tolerance tests in a solid medium are useful to observe the effect that PMs have on the growth of filamentous fungi (morphological changes) and on the selection of fungi with the potential to recover PMs from primary or secondary sources. It was found that the most tolerant fungal genera for Au are Aspergillus and Fusarium, while those for Ag are Trichoderma and Fusarium. Lastly, we found that the chemical form of Pt does not have an inhibitory effect on the growth of most of the used fungi.

Finally, it is important to highlight that the results reported here could be complemented with new experiments that allow the development of possible biotechnological applications. For instance, 
the capacity of the most resistant fungi to extract suitable precious metals should be evaluated. Likewise, the morphological and coloration changes observed for the different fungi could help to develop low-cost sensors for the assessment of toxicity in contaminated water samples.

Author Contributions: Conceptualization, R.A.-D. and M.J.G.-M.; methodology, R.A.-D.; investigation and formal analysis, R.A.-D. and M.J.G.-M.; data curation, R.A.-D., M.J.G.-M. and R.U.-K. writing-original draft preparation, R.A.-D. and M.J.G.-M.; writing-review and editing, R.A.-D.; M.J.G.-M. and R.U.-K.; funding acquisition, R.A.-D. All authors have read and agreed to the published version of the manuscript.

Funding: This research was funded by Consejo Nacional de Ciencia y Tecnología-CONACYT of Mexico, from the Basic Science Project-SEP, grant number 239601.

Acknowledgments: Thanks to the Unit of Support Services in Analytical Resolution of the Universidad Veracruzana.

Conflicts of Interest: The authors declare no conflict of interest.

\section{References}

1. Balcerzack, M. Sample digestion methods for the determination of traces of precious metals by spectrophotometric techniques. Anal. Sci. 2002, 18, 737-750. [CrossRef]

2. Baltzer, N.; Copponnex, T. Precious Metals of Biomedical Applications, 1st ed.; Elsevier Science: Cambridge, UK, 2014; 236p.

3. Butler, J. Precious materials handbook. Platin. Met. Rev. 2012, 56, 267-270. [CrossRef]

4. Thakor, A.S.; Jokerst, J.; Zaveleta, C.; Massoud, T.F.; Gambhi, S.S. Gold nanoparticles: A revival in precious metal administration to patients. Nano Lett. 2011, 11, 4029-4036. [CrossRef]

5. Dobson, R.S.; Burgess, J.E. Biological treatment of precious metal refinery wastewater: A review. Miner. Eng. 2007, 20, 519-532. [CrossRef]

6. Wang, M.; Tan, Q.; Chiang, J.F.; Li, J. Recovery of rare and precious metals from urban mines-A review. Front. Environ. Sci. Eng. 2017, 11, 1-17. [CrossRef]

7. Fomina, M.; Ritz, K.; Gadd, G.M. Nutritional influence on the ability of fungal mycelia to penetrate toxic metal-containing domains. Mycol. Res. 2003, 107, 861-871. [CrossRef] [PubMed]

8. Bruins, M.R.; Kapil, S.; Oehme, F.W. Microbial resistance to metals in the environment. Ecotox. Environ. Safe 2000, 45, 198-207. [CrossRef] [PubMed]

9. Davis, T.A.; Volesky, B.; Mucci, A. A review of the biochemistry of heavy metal biosorption by brown algae. Water Res. 2003, 37, 4311-4330. [CrossRef]

10. Ehrlich, H.L. Microbes and metals. Appl. Microbiol. Biotechnol. 1997, 48, 687-692. [CrossRef]

11. Gadd, G.M. Metals, minerals, and microbes: Geomicrobiology and bioremediation. Microbiology 2010, 156, 609-643. [CrossRef]

12. Liu, G.; Ling, S.; Zhan, X.; Lin, Z.; Zhang, W.; Lin, K. Interaction effects and mechanism of Pb pollution and soil microorganism in the presence of earthworm. Chemosphere 2017, 173, 227-234. [CrossRef] [PubMed]

13. Roane, T.M.; Pepper, L.L.; Gentry, T.L. Microorganisms and metal pollutants. In Environmental Microbiology, 3rd ed.; Pepper, L.L., Gerba, C.P., Gentry, T.J., Eds.; Academic Press: Salt Lake City, UT, USA, 2014; pp. 415-439.

14. Sterritt, R.M.; Lester, J.N. Interactions of heavy metals with bacteria. Sci. Total Environ. 1980, 14, 5-17. [CrossRef]

15. Xue, H.; Stumm, W.; Sigg, L. The binding of heavy metals to algal surfaces. Water Res. 1988, 22, 917-926. [CrossRef]

16. Kaksonen, A.H.; Mudunuru, B.M.; Hackl, R. The role of microorganisms in gold processing a recovery: A review. Hydrometallurgy 2014, 142, 70-83. [CrossRef]

17. Li, M.; Tian, H.; Wang, L.; Duan, J. Bacterial diversity in linglong gold mine, China. Geomicrobiol. J. 2017, 34, 267-273. [CrossRef]

18. Reith, F.; Lengke, M.F.; Falconer, D.; Craw, D.; Southam, G. The geomicrobiology of gold. ISME J. 2007, 1, 567-584. [CrossRef]

19. Sanyal, S.K.; Shuster, J.; Reith, F. Cycling of biogenic elements drives biogeochemical gold cycling. Earth Sci. Rev. 2019, 190, 131-147. [CrossRef]

20. Shuster, J.; Southam, G. The in-vitro "growth" of gold grains. Geology 2015, 43, 79-82. [CrossRef]

21. Devasia, P.; Natarajan, K.A. Bacterial leaching: Biotechnology in the mining Industry. Resonance 2004, 9, 27-34. [CrossRef] 
22. Gonzalez, R.; Gentina, J.C.; Acevedo, F. Biooxidation of a gold concentrate in a continuous stirred tank reactor: Mathematical model and optimal configuration. Biochem. Eng. J. 2004, 19, 33-42. [CrossRef]

23. Kaksonen, A.H.; Perrot, F.; Morris, C.; Rea, S.; Benvie, B.; Austin, P.; Hackl, R. Evaluation of submerged bio-oxidation concept for refractory gold ores. Hydrometallurgy 2014, 141, 117-125. [CrossRef]

24. Mubarok, M.Z.; Winarko, R.; Chaerun, S.K.; Rizki, I.N.; Ichlas, Z.T. Improving gold recovery from refractory gold ores through biooxidation using iron-sulfur-oxidizing/sulfur-oxidizing mixotrophic bacteria. Hydrometallurgy 2017, 168, 69-75. [CrossRef]

25. Muravyov, M. Two-step processing of refractory gold-containing sulfidic concentrate via biooxidation at two temperatures. Chem. Pap. 2019, 73, 173-183. [CrossRef]

26. Olson, G.J. Microbial oxidation of gold ores and gold bioleaching. FEMS Microbiol. Lett. 1994, 119, 1-6. [CrossRef]

27. Rawlings, D.E.; Silver, S. Mining with microbes. Nat. Biotechnol. 1995, 13, 773-778. [CrossRef]

28. Schippers, A.; Hedrich, S.; Vasters, J.; Drobe, M.; Sand, W.; Willscher, S. Biomining: Metal Recovery from Ores with Microorganisms. In Geobiotechnology I. Advances in Biochemical Engineering/Biotechnology; Schippers, A., Glombitza, F., Sand, W., Eds.; Springer: Berlin/Heidelberg, Germany, 2013; Volume 41, pp. 1-47.

29. Alshehri, A.N.Z. Microbial recovery of gold metal from untreated and pretreated electronic wastes by wild and mutated cyanogenic Bacillus megaterium. Am. J. Microbiol. Res. 2018, 6, 14-21.

30. Arshadi, M.; Mousavi, S.M. Enhancement of simultaneous gold and copper extraction from computer printed circuit boards using Bacillus megaterium. Bioresour. Technol. 2015, 175, 315-324. [CrossRef]

31. Brandl, H.; Lehmann, S.; Faramarzi, M.A.; Martinelli, D. Biomobilization of silver, gold, and platinum from solid waste materials by HCN-forming microorganisms. Hydrometallurgy 2008, 94, 14-17. [CrossRef]

32. Argumedo-Delira, R.; Díaz-Martínez, M.E.; Gómez-Martínez, M.J. Microorganisms and plants in the recovery of metals from the printed circuit boards of computers and cell phones: A mini review. Metals 2020, 10, 1120. [CrossRef]

33. Kumar, A.; Saini, H.S.; Kumar, S. Bioleaching of gold and silver from waste printed circuit boards by Pseudomonas balearica SAE1 isolated from an e-waste recycling facility. Curr. Microbiol. 2018, 75, 194-201. [CrossRef]

34. Natarajan, G.; Ting, Y.-P. Pretreatment of e-waste and mutation of alkali-tolerant cyanogenic bacteria promote gold biorecovery. Bioresour. Technol. 2014, 152, 80-85. [CrossRef] [PubMed]

35. Tay, S.B.; Natarajan, G.; Rahim, M.N.B.A.; Tan, H.T.; Chung, M.C.M.; Ting, Y.P.; Yew, W.S. Enhancing gold recovery from electronic waste via lixiviant metabolic engineering in Chromobacterium violaceum. Sci. Rep. 2013, 3, 1-7. [CrossRef] [PubMed]

36. Argumedo-Delira, R.; Gómez-Martínez, M.J.; Soto, B.J. Gold bioleaching from printed circuit boards of mobile phones by Aspergillus niger in a culture without agitation and with glucose as a carbon source. Metals 2019, 9, 521. [CrossRef]

37. Bindschedler, S.; Vu Bouquet, T.Q.T.; Job, D. Fungal biorecovery of gold from e-waste. Adv. Appl. Microbiol. 2017, 99, 53-81.

38. Madrigal-Arias, J.E.; Argumedo-Delira, R.; Alarcón, A.; Mendoza-López, M.R.; García-Barradas, O.; Cruz-Sánchez, J.S.; Ferrera-Cerrato, R.; Jiménez-Fernández, M. Bioleaching of gold, copper and nickel from waste cellular phone PCBs and computer goldfinger motherboards by two Aspergillus niger strains. Braz. J. Microbiol. 2015, 46, 707-713. [CrossRef]

39. Drake, P.L.; Hazelwood, K.J. Exposure-related health effects of silver and silver compounds: A review. Ann. Occup. Hyg. 2005, 49, 575-585.

40. Goddard, P.A.; Bull, A.T. The isolation and characterisation of bacteria capable of accumulating silver. Appl. Microbiol. Biotechnol. 1989, 31, 308-313. [CrossRef]

41. Pareek, V.; Gupta, R.; Panwar, J. Do physico-chemical properties of silver nanoparticles decide their interaction with biological media and bactericidal action? A review. Mater. Sci. Eng. C. 2018, 90, 739-749. [CrossRef]

42. Slawson, R.M.; Lee, H.; Trevors, J.T. Bacterial interactions with silver. Biol. Metals 1990, 3, 151-154. [CrossRef]

43. Pooley, F.D. Bacteria accumulate silver during leaching of sulphide ore minerals. Nature 1982, 296, 642-643. [CrossRef]

44. Murthy, D.S.R. Microbially enhanced thiourea leaching of gold and silver from lead-zinc sulphide flotation tailings. Hydrometallurgy 1990, 25, 51-60. [CrossRef]

45. Rusin, P.; Cassells, J.; Sharp, J.; Arnold, R.; Sinclair, N.A. Bioprocessing of refractory oxide ores by bioreduction: Extraction of silver, molybdenum, and copper. Miner. Eng. 1992, 5, 1345-1354. [CrossRef]

46. Zhappar, N.K.; Shaikhutdinov, V.M.; Kanafin, Y.N.; Ten, O.A.; Balpanov, D.S.; Korolkov, I.V.; Collinson, S.R.; Erkasov, R.S.; Bakibaev, A.A. Bacterial and chemical leaching of copper-containing ores with the possibility of subsequent recovery of trace silver. Chem. Pap. 2019, 73, 1357-1367. [CrossRef] 
47. Maes, S.; Props, R.; Fitts, J.P.; Smet, R.D.; Vilchez-Vargas, R.; Vital, M.; Pieper, D.H.; Vanhaecke, F.; Boon, N.; Hennebel, T. Platinum recovery from synthetic extreme environments by halophilic bacteria. Environ. Sci. Technol. 2016, 50, 2619-2626. [CrossRef]

48. Madrigal-Arias, J.E. Biolixiviación de Metales Utilizando Bacterias y Hongos a Partir de Desechos Electrónicos. Licentiate Thesis, Universidad Veracruzana, Xalapa, Mexico, 13 December 2012.

49. Wilson, K.H.; Blitchington, R.B.; Greene, R.C. Amplification of bacterial 16 S ribosomal DNA with polymerase chain reaction. J. Clin. Microbiol. 1990, 28, 1942-1946. [CrossRef]

50. Sambrook, J.; Rusell, D.W. Molecular Cloning: A Laboratory Manual, 3rd ed.; Cold Spring Harbor Laboratory Press: New York, NY, USA, 2001; 800p.

51. SAS. Institute Inc. The SAS System for Windows, Version 9.4; SAS Institute Inc.: Cary, NC, USA, 2018.

52. Baldrian, P.; Gabriel, J. Effect of heavy metals on the growth of selected wood-rotting basidiomycetes. Folia Microbiol. 1997, 42, 521-523. [CrossRef]

53. Baldrian, P. Interactions of heavy metals with white-rot fungi. Enzyme Microb. Technol. 2003, 32, 78-91. [CrossRef]

54. Guillén, Y.; Machuca, Á. The effect of copper on the growth of wood-rotting fungi and a blue-stain fungus. World J. Microb. Biot. 2008, 24, 31-37. [CrossRef]

55. Kowshik, M.; Nazareth, S. Metal tolerance of Fusarium solani. Ecol. Environ. Conserv. 2000, 6, 391-395.

56. Nazareth, S.; Marbaniang, T. Effect of heavy metals on cultural and morphological growth characteristics of halotolerant Penicillium morphotypes. J. Basic Microbiol. 2008, 48, 363-369. [CrossRef]

57. Biryuzova, V.I.; Korobushkina, E.D.; Pozmogova, I.N.; Karavaiko, G.I. Accumulation of gold by cell Candida utilis. Mikrobiologiya 1987, 56, 155-161.

58. Karamushka, V.I.; Gadd, G.M. Interaction of Saccharomyces cerevisiae with gold: Toxicity and accumulation. BioMetals 1999, 12, 289-294. [CrossRef]

59. Novelli, F.; Recine, M.; Sparatore, F.; Juliano, C. Gold (I) complexes as antimicrobial agents. Farmaco 1999, 54, 232-236. [CrossRef]

60. Martínez-Aldino, I.Y. Estudio de la Respuesta Fisiológica de Fusarium Oxysporum MX17 y Fusarium Solani MXPE15 al Cultivarse en Medios con AuCl3. Licentiate Thesis, Universidad Veracruzana, Xalapa, Mexico, 7 January 2016.

61. Díaz-Martínez, M.E.; Argumedo-Delira, R.; Sánchez-Viveros, G.; Alarcón, A.; Mendoza-López, M.R. Microbial bioleaching of $\mathrm{Ag}$, $\mathrm{Au}$ and $\mathrm{Cu}$ from printed circuit boards of mobile phone. Curr. Microbiol. 2019, 76, 536-544. [CrossRef] [PubMed]

62. Piimpel, T.; Schinner, F. Silver tolerance and silver accumulation of microorganisms from soil materials of a silver mine. Appl. Microbiol. Biotechnol. 1986, 24, 244-247. [CrossRef]

63. Díaz-Martínez, M.E. Plantas y Microorganismos Útiles en la Recuperación de Metales Provenientes de Residuos Electrónicos. Ph.D. Thesis, Universidad Veracruzana, Xalapa Veracruz, México, February 2019.

64. LeRoy, A.F. Interactions of platinum metals and their complexes in biological systems. Environ. Health Perspect. 1975, 10, 73-78. [CrossRef] [PubMed]

65. Rosenberg, B.; Renshaw, E.; Vancamp, L.; Hartwick, J.; Drobnik, J. Platinum-induced filamentous growth in Escherichia coli. J. Bacteriol. Res. 1967, 93, 716-721. [CrossRef] [PubMed]

Publisher's Note: MDPI stays neutral with regard to jurisdictional claims in published maps and institutional affiliations.

(C) 2020 by the authors. Licensee MDPI, Basel, Switzerland. This article is an open access article distributed under the terms and conditions of the Creative Commons Attribution (CC BY) license (http://creativecommons.org/licenses/by/4.0/). 